\title{
The Effect of Competence, Work Experience, and Internal Control Auditor's on Audit Quality (Case Study on Internal Auditors of PT Bank Rakyat Indonesia (BRI) Tbk)
}

\author{
Ananda Liana Putri ${ }^{1 *}$, Nengzih Nengzih ${ }^{2}$ \\ ${ }^{1,2}$ Department of Accounting, Faculty of Economic and Business, Mercu Buana University, Jakarta, Indonesia
}

DOI: $10.36348 /$ sjef.2021.v05i04.001 $\quad$ | Received: 06.03.2021 | Accepted: 03.04.2021 | Published: 06.04 .2021

*Corresponding author: Ananda Liana Putri

\section{Abstract}

Knowing the impact of the auditor's competence, work experience, and internal control on audit quality is a goal to be achieved. This type of research uses quantitative research with saturated samples. The data collection technique is primary data that comes from questionnaires, then secondary data is taken from company documentation. The population in this research was 32 internal auditors as respondents at PT Bank Rakyat Indonesia (BRI) Tbk, which is headquartered in Jakarta in the Internal Audit Unit (SKAI). The data analysis technique used SEM with Smart PLS software for windows version 3.0. The results of this research show that audit quality is significantly affected by auditor's internal control, while competence and work experience have no significant effect.

Keywords: Competence, Work Experience, Internal Control, Audit Quality.

Copyright () 2021 The Author(s): This is an open-access article distributed under the terms of the Creative Commons Attribution 4.0 International License (CC BY-NC 4.0) which permits unrestricted use, distribution, and reproduction in any medium for non-commercial use provided the original author and source are credited.

\section{INTRODUCTION}

Various sectors in the industry in Indonesia, especially the public and private sectors, are required to take various strategic steps in achieving their goals, such as reassessing and monitoring company performance by a professional in their field or external and internal auditors. In the research about the role of internal audit in corporate governance and management. The institute of internal auditors reports the United States on the New York Stock Exchange or most other stock exchange institutions, requiring publicly listed companies to have internal auditors to make it easier for companies to evaluate risk management and internal control. Some private companies also make an internal audit section in their organization even though there is no obligation on them [1].

The function of the audit intern or internal checking is made to test and review the activities of the organization or institution where the assessment is carried out and is assessed objectively and independently. In the public sector, such as government institution, BUMN, and BUMD, there are internal auditors who are scattered in the workplace, as well as in the private sector. At the top management always relies on internal checks with equipment presentation of assessments, objective analysis, and various recommendations in controlling the implementation of organizational activities [2]. Then, after this has been done, the auditor draws and makes several conclusions which then deliver these conclusions to management/top management. After top management seeing the results of the internal auditor's examination, it will make strategic decisions that will be made. So that the decisions to be taken can provide maximum and quality decisions.

And then, internal auditors must be able to disclose findings ranging from fraud, violations of standard operating procedures and actions that can indicate financial or non-financial losses to the company that have occurred in agencies/organizations based on code principles internal auditor ethics such as integrity, objectivity, confidentiality, and competency so as to produce audit reports that have an impact on audit quality. According to the American Accounting Association (AAA), the Financial Accounting Standards Committee states that an auditor who is "capable" of getting violations is a competent auditor. Meanwhile, the auditor who is "willing" to state that if there are any violations, the auditor is an independent auditor [1]. This is consistent with the research of Mustafa Üç and Edvin Haxhiraj [2] shows that the perception of internal auditors has a positive effect on 
performance standards and standard attributes of each on the quality of internal audit.

To produce result inspection or quality audit, of course a profession code of ethics is needed. Where the measurement of the quality implementation tasks in completing profession responsibilities is called a code of ethics. Meanwhile, the provisions that need to be fulfilled in maintaining the quality of an internal auditor's performance and the quality of the results examinations that has been carried out are the internal auditor profession practice standards [3]. The code of ethics must be fulfilled by an auditor and the organization in carrying out internal audit activities. One of the principles audit intern code of ethics which applicable is competence. One of the cases shows that the auditor violates the principles of internal audit which is less of integrity, where the auditor accepts bribes to influence the audit results and violates the principle of competence. For competence itself, is behavior of auditors to resolved problems and measured by factors of intellectual, emotional, and social abilities to improve performance so as to produce quality audit [4].

Another cause related to low audit results is the work experience factor. Based on several phenomena related to the experience that the auditor has, it can affect the quality of audit. One example of a case that occurs is credit fraud by an internal person in one of the bank corporation. There was a credit error that violated the procedure with an alleged error of value of 30 billion, but in fact it was 7 billion. With the occurrence of procedural errors carried out by internal person, it can be caused by less of experience. For work experience itself, which is understanding and carrying out work tasks that are directly involved with good results as measured by using several indicators of work and equipment [5]. Experienced auditors have several advantages when detecting an error and understanding the error accurately and finding out the cause of the error that occurred [6].

Another factor that is thought to trigger the cause of the low quality audit is internal control factors. Such as the phenomenon that occurred in PDAM Tirtawening. Where there is a wrong recording of unreliable PDAM bills or it can be called incorrect recording of the meter, this can happen because of an internal person who deliberately installed illegal water connections. With this case, it means that the internal control is not given enough attention in company. For internal control itself, namely the process carried out by the organization / company that is influenced by the director, management, and other personnel to achieve the goals of the company related to reporting, operations, and compliance which are then measured using components in assessing a risk, environmental management, control of information communication companies, and internal activities [7]. Of the various activities, of course it is necessary to have internal control so that the operational activities of the company can increase and achieve the objectives to be achieved by an entity.

Therefore, internal auditors are expected to continuously improve the quality of audit services supported by competence, experience, and good internal control so that when making judgments it can provide strategic results for the company. As the result of research Yudi which shows that experienced auditors are not affected by information that is irrelevant in making going-concern judgments, but experience can reduce the impact of information that is not relevant to the auditor's judgment [10]. This is in accordance with attribution theory, in which Fritz Heider introduced a theory, namely attribution theory.

Attribution theory explains the process of individuals trying to explain the reasons for the occurrence of an event and trying to explain how the causes of the resulting behavior [8]. The attribution process can make important things in understanding the behavior of other people because it is used to find out the extent to which individual behavior shows of a quality so that it can be useful in helping understand the resulting behaviors. The research by Bonner [12] about attribution theory shows that the behavior of individuals who are related to decision making can be caused by several factors such as person, task, and environment [9].

\section{LITERATURE REVIEW AND DEVELOPMENT HYPOTHESIS Competency and Audit Quality}

Competence is expertise in doing a profession, aka work. A competent person means being able to carry out a job from the responsibility that has been accepted and of course with maximum quality results. The broad meaning of competence includes the ability of knowledge or knowledge, as well as good skills and good behavior in carrying out the work or profession in which it is carried out [13]. An auditor must be competent and have sufficient knowledge and abilities so that the task as an auditor by producing good quality is achieved. Research of Muhammad Laras Widyanto, etc shows that the quality of internal auditors is influenced by competence. So that if the competence of an auditor increases, it will further ensure that the resulting audit quality continues to be good. The results of a similar research by [14] Agneus et al. [15] Ni made Dian Rosita and I Made Sukarta, also shows that competence has a positive effect on the quality of audit. The better role of internal audit, the higher it is to prevent fraud. So that the first hypothesis in this study is:

\section{H1: Competence has an effect on Audit Quality}


Ananda Liana Putri \& Nengzih Nengzih., Saudi J Econ Fin, Apr, 2021; 5(4): 133-140

Work Experience and Audit Quality

Experience is a measure about long time has been journey of someone to understand the duties of the job and have done them well [16]. Implementing an audit activity, high professionalism needs to be possessed by auditors to carry out their duties. According to Tubbs [17] suggests that an expert auditor has the advantage of detecting an error accurately and finding the cause of the error.

The knowledge of an auditor can give the big effect on audit quality [18]. Agus [19] disclose that an auditor's research must be professional and have work experience, experience in auditing activities and official learning. In the accounting profession, there are 2 things that must be fulfilled in order to create an effective audit and good result. Result of research Fransiska and Betri, luh gede ayu nidya wulandari, et al. [20], Melody Iskandar [21], Ni Made Widia [22], and I Gede Adi [23] showing that experience has an effect on auditor in creating good audit quality. So that the second research hypothesis is as below:

H2: Work Experience has an effect on Audit Quality

\section{Internal Control and Audit Quality}

Internal control is procedures and policies designed to provide appropriate decisions to management that the company has achieved these goals, about reliability of financial reporting, efficiency and effectiveness of operations as well as compliance with laws and regulations [24]. In order to create good quality audit results is must have to understanding about internal control. The level of auditor's awareness about internal operations will have an effect on their performance in the field. Research result of Nurdin [25] is internal control has a good effect on audit quality. Increasing internal control can improve the quality of audits and the quality of reports submitted to management. The existence of an internal audit function will improve control and fraud detection in company operations. The similar research result by Mietinnen in Adyatma [26], and Peter explain that internal control is effect on audit quality. So that the third hypothesis in this study below:

\section{H3: Internal Control Auditor has an effect on Audit Quality}

\section{RESEARCH METHODOLOGY}

This method will explain the types of data and data sources as well as the methods used in testing this relationship.

\section{Data, Population, and Sample}

The population of this study is 32 respondents at PT Bank Rakyat Indonesia (BRI) Tbk as internal auditors. The object of this research is headquartered in Jakarta in the Internal Audit Unit (SKAI). This type of research is a quantitative method. The sampling technique (sampling) is nonprobability sampling with saturated sampling. The data collection technique is primary data that comes from questionnaires, then secondary data is taken from company documentation. Distribution of questionnaires to respondents via google form. At period June 11 to December 2, 2020. The data collected by internal auditors consisted of 24 male internal audit respondents and 8 female respondents.

\section{DATA ANALYSIS}

Methods of data analysis using SEM (Structural Equation Model) with Smart Partial Least Square (PLS) software for windows version 3.0. Data analysis consisted of testing the validity and reliability of the instrument, evaluating the inner model and outer model, and then testing the hypothesis.

\section{RESULTS AND DISCUSSION Evaluation of Outer Model (Measurement Model)}

The analysis of the outer model was carried out using the validity test, with convergent validity and discriminant validity, and then for reliability test was Croncah's alpha and composite reliability.

\section{Validity Test}

\section{Convergent Validity}




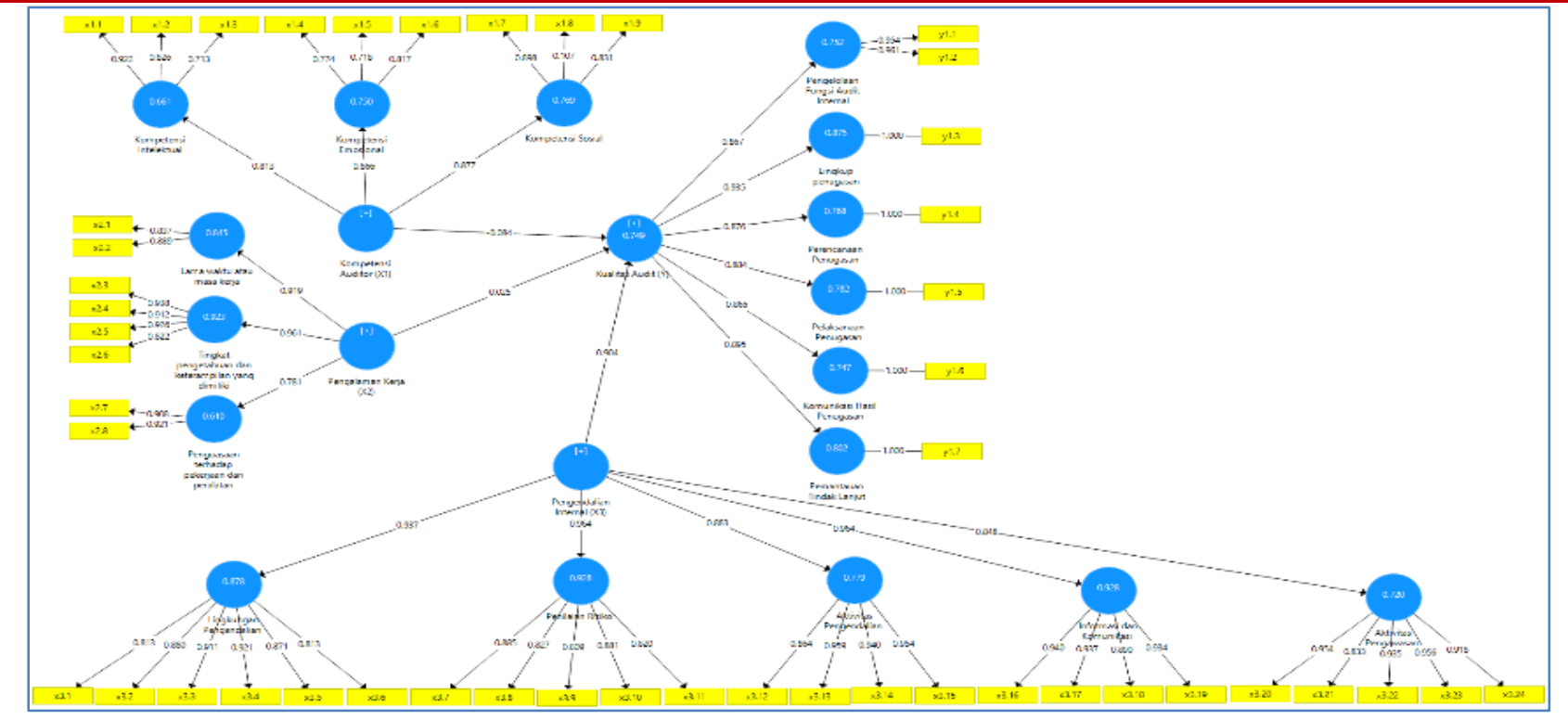

Fig-1: First Outer Loading

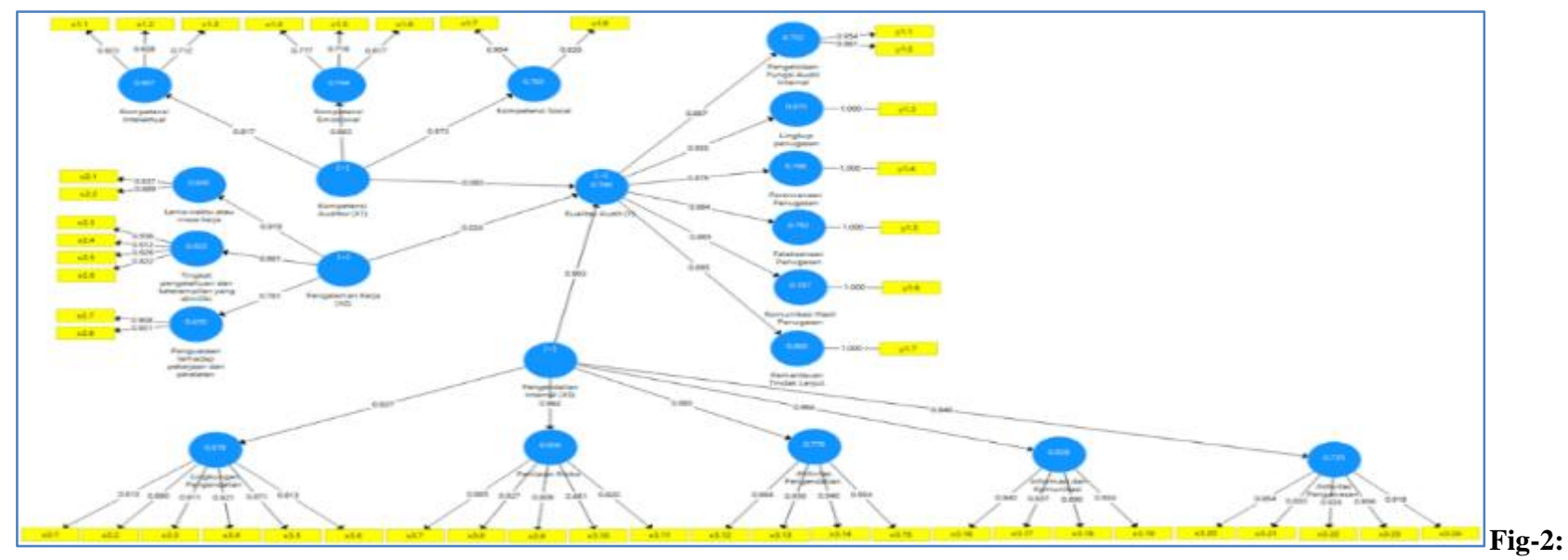

Second Outer Loading

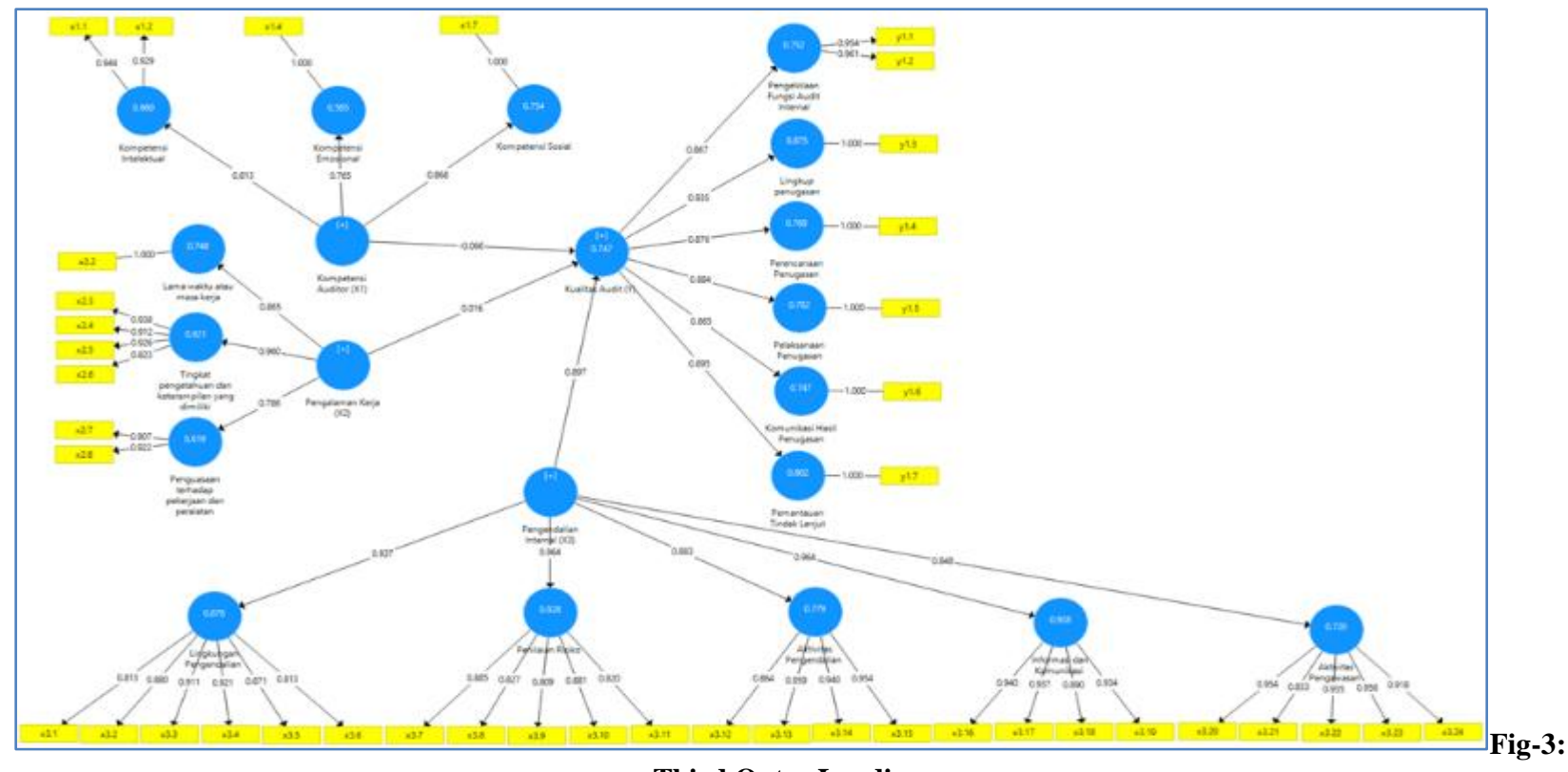

Third Outer Loading

(c) 2021 | Published by Scholars Middle East Publishers, Dubai, United Arab Emirates 
A statement or research variable is declared valid if it has a loading factor value $>0.5$ [27].

In Figure 1 it is known that there is an indicator that is tested invalid, is $\mathrm{x} 1.8$, so that this invalid indicator is dropped / removed then the second test is repeated.

The validity test in Figure 2 shows that there are still invalid indicators, X1.3, X1.5, X1.6, X1.9 and $\mathrm{X} 2.1$ next, these indicators are dropped and the validity test is repeated.

Based on Figure 3 above, it is known that all indicators for the competency variables, work experience, internal control, and audit quality have been tested valid. The complete results of the validity test using PLS Bootstrapping.

\section{Discriminant Validity}

A reliability component has high discriminant validity if AVE is above 0.50. The AVE test results as below:

Table-1: AVE results

\begin{tabular}{|l|l|l|}
\hline No. & Variable & AVE \\
\hline 1. & Competence $(\mathrm{X} 1)$ & 0,418 \\
\hline 2. & Work Experience $(\mathrm{X} 2)$ & 0,658 \\
\hline 3. & Internal Control (X3) & 0,675 \\
\hline 4. & Audit Quality (Y) & 0,764 \\
\hline
\end{tabular}

The results of table 1, work experience and internal control variables have an AVE above 0.5, while the competency variable has an AVE of 0.418 which means that it is below 0.5 but it can still be said to be sub marginal, so it can be concluded that the competency variables, work experience, and internal control variable has high discriminant validity.

\section{Reliability Test}

Reliability test was conducted to measure the level of reliability of research measuring instruments with the criteria of composite reliability and cronbach's alpha $>0,70$. The results of the reliability test are as below:

Table-2: Composite Reliability Test

\begin{tabular}{|l|l|}
\hline Variable & Composite Reliablity \\
\hline Competency (x1) & 0.847 \\
\hline Work Experience (x2) & 0.938 \\
\hline Internal Control (x3) & 0.980 \\
\hline Audit Quality (y) & 0.958 \\
\hline
\end{tabular}

Table 2. Shows the results of the composite reliability value of all research variables is more than 0.70 . It can be concluded that all variables have high reliability.

Table-3: Cronbach's Alpha Test

\begin{tabular}{|l|l|}
\hline Variable & Cronbach's Alpha \\
\hline Competency (x1) & 0.810 \\
\hline Work Experience (x2) & 0.924 \\
\hline Internal Control (x3) & 0.979 \\
\hline Audit Quality (Y) & 0.948 \\
\hline
\end{tabular}

The results of table 3 above show that the Cronbach's alpha value of all research variables is more than 0.70. It can be concluded that all construct indicators are reliable.

\section{Testing the Goodness of Fit of the Structural Model} (Inner Model)

\section{R-Square Value}

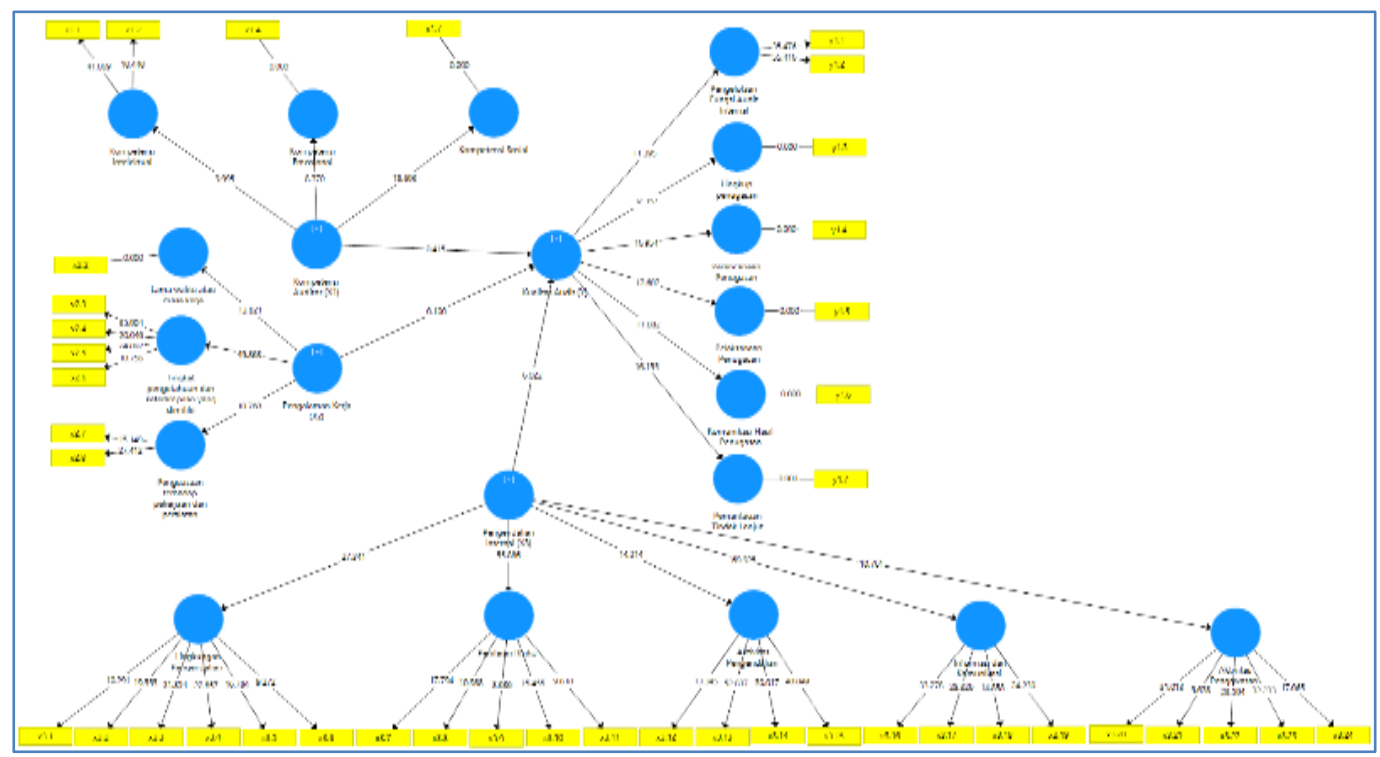

Fig-4: Bootstrapping 
Ananda Liana Putri \& Nengzih Nengzih., Saudi J Econ Fin, Apr, 2021; 5(4): 133-140

\begin{tabular}{|l|l|l|}
\hline \multicolumn{3}{|c|}{ Table-4: R-Square Value } \\
\hline Variable & R Square & $\begin{array}{l}\text { R Square } \\
\text { Adjusted }\end{array}$ \\
\hline Audit Quality (Y) & 0,747 & 0,720 \\
\hline
\end{tabular}

$\mathrm{R}^{2}$ is the coefficient of determination that is part of the total variation in the dependent variant explained by the variation in the independent variable. The value of Q Square in this study is:

Based on table 4, it is known that the variables of competence, work experience, auditor internal control, and audit quality provide R-Square value of 0.747 . This means that the construct variables of audit quality which can be explained by the construct variables of the influence of competence, work experience, and auditors' internal control are $74.70 \%$, while $25.30 \%$ are explained by other variables not included in the research model.

\section{Q-Square Value (Predictive Relevance)}

Q-Square (Predictive Relevance) is performed to determine the predictive capability with a blindfolding procedure. If the value obtained is 0,02 (small), 0, 15 (medium) and 0, 35 (large). According to Wati [27], the value of Predictive Relevance $\left(Q^{2}\right)$ is calculated by the formula:

$\mathrm{Q}^{2}=1-\left(1-\mathrm{R} 1^{2}\right)\left(1-\mathrm{R}^{2}\right) \ldots \mathrm{n}$

$\mathrm{Q}^{2}=1-\left(1-\mathrm{R}^{2}\right)$
$\mathrm{Q}^{2}=0,558$

The value of Q Square or predictive relevance for the structural model in this study is 0.558 or $55.8 \%$ is included in the large value category, meaning that the model is able to explain the phenomenon of audit quality associated with several variables, competence, work experience, and auditors' internal control. Therefore, the model can be said to be good or the model has a good predictive value. Then the model can be used for hypothesis testing.

\section{Hypothesis test}

The hypothesis can be accepted or supported if the value of T-statistics > T-table (1.701) is at a significant level of $5 \%(0.05)$. The results of the hypothesis test can be seen from the PLS bootstrapping process below:

Table-5: Results of T-statistics

\begin{tabular}{|l|l|l|l|l|}
\hline Hypothesis & Variable & Koefisien Parameter & T Statistik & P Value \\
\hline H1 & Competency & -0.066 & 0.415 & 0.678 \\
\hline H2 & Work Experience & 0.016 & 0.100 & 0.920 \\
\hline H3 & Internal Control & 0.897 & 6.022 & 0.000 \\
\hline
\end{tabular}

\section{Hypothesis testing 1: Competency has effects of audit quality}

The result of the competency path parameter coefficient ( $\mathrm{x} 1)$ on audit quality $(\mathrm{y})$ is -0.066 with a Tstatistic value of $0.415<1.701$ at the $5 \%$ significance level, so that the auditor's competence does not have a significant effect on audit quality (y), thus hypothesis 1 (H1) rejected. This study is similar with the results of research by Carolita and Rahardjo [29] which found that competence does not have a significant effect on audit quality. The others research by Dewa Ayu and I Ketut Budiartha [30], Ponny Harsanti and Aprilia Whetyningtyas [31], shows that competence has no effect on audit quality. However, the result of this research is not similar by Muhammad Laras Widyanto, et al. [32] which has the results of competency research has a significant effect on the quality of internal auditors. Similar research by Agneus et al. [14], Ni made Dian Rosita and I Made Sukarta [15], and Abdul Halim et al. [33] also shows that competence has a positive effect on audit quality.

\section{Hypothesis testing 2: Work Experience has effects of audit quality}

The result of work experience path parameter coefficient (x2) on audit quality (y) is 0.016 and the $\mathrm{T}$ statistic value is $0.100<1.701$ at the $5 \%$ significance level (0.05), so that the work experience of auditors does not have a significant effect on audit quality (y).
Hypothesis $2(\mathrm{H} 2)$ is rejected. The results of this research is similar by Haryadi [31], Badjuri [34], Singgih dan Bawono [35] indicates that work experience has no significant effect on audit quality. In determining whether someone has experience or not, it can be measured by how long an auditor has worked, the level of knowledge and skills, and mastery of work and equipment. Supported by the many phenomena related to auditors who already have a lot of experience in conducting audits, it turns out that they are not necessarily able to improve audit quality. The answer to the results of this research that the application of work experience in company has not been optimal. This is indicated by finding the results of the work experience of auditors with low results at the point, namely the length of time or the working period (based on period working/ length of time that has been taken, the auditor can understand the work tasks). The majority of respondents who answered the questionnaire were 4-6 years of working in corporate, while for those who were more than 10 years, only a few, and the majority of respondents who answered the questionnaire were junior auditors. This means that the work experience of the auditors does not always have an effect on audit quality. Based on the above discussion, it can be concluded that the work experience of auditors does not have a significant effect on audit quality, obtained from the results of data processing on the answers to the questionnaire of this research. However, the results of 
this research is not similar by Fransiska and Betri [28], luh gede ayu nidya wulandari, et al. [20], Melody Iskandar [21], Ni Made Widia [22], and I Gede Adi [23] shows that work experience has an effect on audit quality.

\section{Hypothesis testing 3: Internal Control has effects of audit quality}

The result of internal control path parameter coefficient (x3) on audit quality (y) is 0.897 and the $\mathrm{T}$ statistic value is $6,022>1,701$ at a significance level of $5 \%$, so that auditors' internal control has a significant effect on audit quality (y), thus hypothesis 3 (H3) received. The result of this research is similar with Nurdin [25] which indicates that internal control has a significant effect on audit quality. Increasing internal control will improve the quality of audits and the quality of reports submitted to management. With the internal audit function, it improves control and fraud detection in company operations. The similar result of research by Mietinnen [26] in Adyatma [26], and Peter [36] shows that internal control has an effect on audit quality. This means that the processes carried out by the organization/company that are influenced by the director, management, and other personnel to achieve the entity's objectives relating to operations, reporting and compliance are then measured by components of the control environment, risk assessment, control activities, information and communication and activities control of company have a significant effect so that it improves audit quality. This means that companies as the object of this research have implemented internal controls properly.

\section{CONCLUSION}

Based on purpose in this research and then data processing was carried out using Smart PLS 3.0, the conclusion from the test results showed that the first hypothesis was rejected because audit quality was not significantly affected by competence. This means that the behavior of auditors to resolved problems and measured by these dimensions to improve performance is not necessarily capable of producing quality audits. Then the second hypothesis about audit quality is not significantly effect by work experience. This means that audit quality is not always influenced by work experience. However, the third hypothesis of this research is internal control has a significant effect on audit quality. Improving the dimensions of internal control in the form of assessing a risk, managing activities and the environment, information and communication as well as a series of supervisory activities in a company or entity can certainly improve the quality of the audit itself. This means that the processes carried out by the organization/company that are influenced by the director, management, and other personnel to achieve the goals of the company based on a series of operating activities, reporting, and compliance have a significant effect so as to improve audit quality.

\section{REFERENCES}

1. Widyanto, M. L., Kwarto, F., \& Kurniawati, S. (2018). Pengaruh Kompetensi, Etika, dan Pengalaman Kerja terhadap Kualitas Auditor Internal. Profita, 11(2), 165-182.

2. Hiro, T. (1997). Internal Audit Professional Standards. Jogjakarta: Kanisius.

3. AAA Financial Accounting Standard Committee, Commentary: SEC Auditor Independence Requirements. (2001). Accounting Horizons, 15, 373-386.

4. Üç, M., \& Haxhiraj, E. (2015). The Perceptions on IIA's Standards and Internal Audit Quality: Evidence from Albania Banking Industry. Mediterranean Journal of Social Sciences, 6(1), 147.

5. Amin, W. T. (2008). Management Audit, Jakarta: Rineka Cipta.

6. Spencer, L. M., \& Spencer, P. S. M. (2008). Competence at Work models for superior performance. John Wiley \& Sons.

7. Basit, A., \& Fauzi, N. (2012). The Influence of Experience, Due Professional Care, and Auditor Independence on Audit Quality (Survey on Auditor Inspectorate and BPK RI Representatives of West Java Province). Faculty of Economics, University Computer Indonesia.

8. Tubbs. (1992). The Effect of Experience on Auditor's Organization and Amount of Knowledge. The Accounting Review, vol. 67 (October), 783801.

9. Committee of Sponsoring Organizations of the Treadway Commission. (2013). Internal controlintegrated framework.

10. Shelton, S. W. (1999). The effect of experience on the use of irrelevant evidence in auditor judgment. The accounting review, 74(2), 217-224.

11. Ivancevich, J. M., Konopaske, R., \& Matteson, M. T. (2005). Organizational Behavior and Management, jilid 1 dan 2.

12. Bonner. (2016). The effect of auditor characteristics on audit quality by mediating auditor judgment. Faculty of Economics and Business, Brawijaya University, Malang.

13. Sukrisno, A. (2014). Auditing Practical Guidelines for Accountant Examination by Public Accountants. 4th edition. Book 1. Jakarta: Salemba Empat, 146.

14. Agneus, S. (2016). The Effect of Competence, Independence, and Time Budget Pressure on Audit Quality; 2460-8696.

15. Kusumawati, A., \& Syamsuddin, S. (2018). The effect of auditor quality to professional skepticsm and its relationship to audit quality. International Journal of Law and Management.

16. Foster in A. (2012). Basit and Fauzi Nugraha, "The Influence of Experience, Due Professional Care, and Auditor Independence on Audit Quality (Survey on Auditor Inspectorate and BPK RI Representatives of West Java Province)," Faculty 
of Economics, University Computer Indonesia.

17. Tubbs, R. M. (1992). The effect of experience on the auditor's organization and amount of knowledge. Accounting Review, 783-801.

18. Mulyadi. (2002). Auditing, vol. Book 1, Jakarta: Salemba Empat., 56, 56.

19. Agus, T. (2014). "The influence of professional auditors 'skepticism, audit situation, independence, ethics, expertise and experience on the accuracy of giving auditors' opinions at the Public Accounting Firm in Yogyakarta," Muhamadiyah Journal of Accounting, 1-17.

20. luh gede ayu nidya wulandari and Made Gede Wirakusuma. (2017). "The Effect of Independence, Audit Expertise, Experience and Audit Fee Amounts on Audit Quality," ISSN: 2302-8556 EJournal of Accounting, Udayana University, 21(2); 942-969.

21. Iskandar, M. (2014). Interaction of Independence, Experience, Knowledge, Due Professional Care, Accountability and Job Satisfaction on Audit Quality. 3rd Economics \& Business Research Festival.

22. Ni Made, W., \& I Putu Sudana. (2018). "The Effect of Experience, Due Professional Care and Auditor Accountability on Audit Quality," E-Journal of Accounting at Udayana University, Vols. 22(1); 438-463.

23. Gede, A., \& I Gede, S. (2013). "The Influence of Professionalism, Independence, and Experience of Auditors on the Audit Quality of the Village Credit Institution Supervisory Agency (Lpd),"

24. Arens, A. A., Elder, R. J., \& Mark, B. (2012). Auditing and assurance services: an integrated approach. Boston: Prentice Hall.

25. Nurdin. (2016). "The effect of internal control, independence, work experience, and auditor competence, on audit quality," FEB Mercu Buana University, Jakarta.

26. Miettinen, J. (2007). Audit quality and the relationship between auditee's agency problems and financial information quality: Research proposal. Department of Accounting and Finance University of Vaasa, 1-33.
27. Wati, L. N. (2018). Applied Research Methodology, Pustaka Amri second edition, 8.

28. Arens, A. A., Elder, R. J., \& Mark, B. (2012). Auditing and assurance services: an integrated approach. Boston: Prentice Hall.

29. Carolita, M. K., \& Rahardjo, S. N. (2012). Pengaruh Pengalaman Kerja, Independensi, Objektifitas, Integritas, Kompetensi, Dan Komitmen Organisasi Terhadap Kualitas Hasil Audit (Studi Pada Kantor Akuntan Publik Di Semarang) (Doctoral dissertation, Fakultas Ekonomika dan Bisnis).

30. Dewi, D. A. C., \& Budiartha, I. K. (2015). Pengaruh kompetensi dan independensi auditor pada kualitas audit dimoderasi oleh tekanan klien. E-Jurnal Akuntansi, 11(1), 197-210.

31. Harsanty, P., \& Whetyningtyas, A. (2014). Pengaruh Kompetensi, Independensi, Dan Profesionalisme Auditor Terhadap Kualitas Audit (Studi Empiris Pada Kantor Akuntan Publik Di Semarang). Jurnal Sosial Budaya, 7(1), 1-6.

32. Widyanto, M. L., Kwarto, F., \& Kurniawati, S. (2018). Pengaruh Kompetensi, Etika, dan Pengalaman Kerja terhadap Kualitas Auditor Internal. Profita, 11(2), 165-182.

33. Halim, H. A., Ahmad, N. H., Ramayah, T., \& Hanifah, H. (2014). The growth of innovative performance among SMEs: Leveraging on organisational culture and innovative human capital. Journal of Small Business and Entrepreneurship Development, 2(1), 107-125.

34. Badjuri, A. (2011). Faktor-Faktor fundamental, mekanisme coorporate governance, pengungkapan coorporate social responsibility (CSR) perusahaan manufaktur dan sumber daya alam di Indonesia. Dinamika Keuangan dan Perbankan, 3(1), 38-54.

35. Singgih, E. M., \& Bawono, I. R. (2010). Pengaruh Independensi, Pengalaman, Due Professional Care dan Akuntabilitas Terhadap Kualitas Audit. Simposium Nasional Akuntansi XIII, 1-21.

36. Peter, J. P., \& Donnelly, J. H. (2013). Marketing management: Knowledge and skills. McGraw-Hill Irwin. 